\title{
Post-Normal Science in a German Landscape
}

Roger A. Pielke, Jr.

\begin{abstract}
This essay explores the management and creation of ignorance via an exploration of the landscape of eastern Germany, which has seen profound social, political, and technological changes over the past several decades. Like in many places around the world decision makers in eastern Germany are seeking to reach a future state where seemingly conflicting outcomes related to the economy and the environment are simultaneously realized. The management of ignorance is an important but often overlooked consideration in decision making that the concept of "post-normal science" places into our focus of attention.
\end{abstract}

\section{KEYWORDS}

decision making, energy policy, Germany, ignorance, post-normal science, uncertainty

\section{Introduction}

Several decades ago, Jerry Ravetz and Silvio Funtowicz introduced the notion of "post-normal science" to describe situations where "facts are uncertain, values are in dispute, stakes are high, and decisions urgent" (e.g., Funtowicz and Ravetz 1992, 1993, 1994). In May 2011 scholars gathered in Hamburg to consider new perspectives on post-normal science. Ravetz (2004: 9) has argued that in situations of high uncertainties and incommensurable values creative approaches to decision making will be necessary, beyond those that we typically associate with experts in policy settings: "we have the sorts of problems for which even the professionals' skills and commitment are insufficient; where deep uncertainty or even ignorance swamps our knowledge, and where the value-commitments of participants set incompatible frameworks for the policy issue in dispute."

In this essay I discuss several situations consistent with the notion of post-normal science in which ignorance appears to overwhelm knowledge, yet decisions will nonetheless be taken. In some cases, ignorance has been effectively managed as part of a quest for cer- 
tainty in decision outcomes. In other situations, knowledge of ignorance and its social construction are ignored (ironically enough), sometimes as a matter of practice, which ultimately threatens the ability of decision makers to achieve widely desired outcomes. The management of ignorance is an important but often overlooked consideration in decision making that the concept of post-normal science places into our focus of attention.

This essay explores the concept of ignorance through a discussion of the landscape of eastern Germany, which has seen profound social, political, and technological changes over the past several decades. Decision makers in eastern Germany are seeking to reconcile seemingly incommensurate outcomes related to the economy and the environment. A challenge for eastern Germany lies in the fact that its economy has for many decades relied on the subsurface mining of brown coal. How does a region manage a transition from an economy built on brown coal-which has certain environmental impacts and an uncertain economic future-to an alternative future?

The decision context faced in eastern Germany is in some respects a microcosm of a larger decision context for Germany as a whole. In the aftermath of the Japanese nuclear crisis at Fukushima and changes in the perspectives of the German electorate, Chancellor Angela Merkel has proposed that the nation abandon its nuclear fleet. How does Germany manage a broad transition away from nuclear power without increased reliance on fossil fuels? While the proper response to this question might lie in the realm of ignoranceno one in fact knows the answer-we might gain perspective by taking a look at what is actually happening in the German landscape where communities in eastern Germany are seeking to transition their economies away from the mining of brown coal mining.

The scale of an open pit coal mine is hard to comprehend. Standing on the edge of one such mine just outside of Leipzig during the spring of 2011 I had an impossible time trying to position my camera in such a way as to capture the magnitude of what I was seeing. In fact, camera aside, my eyes had a hard time capturing the enormity of the mine in a single glance and my brain did not seem up to the task of processing what it was that I was actually seeing. As I struggled, a tiny truck with tires no doubt taller than me crawled along the bottom of the pit, looking like a child's toy.

Comprehending that which is right before our eyes is often difficult. But making some sense of this enormous gash in the earth where coal was being systematically taken from the subsurface leaving a giant 
empty pit is key to understanding some of the current challenges that the world faces in meeting what can seem to be incommensurate societal goals for energy, environment, economy, culture, and security.

Statements by leading German politicians in the context of recent policy change have fostered optimism that it is possible to reconcile goals to provide energy supply at reasonable costs while maintaining a healthy rate of economic growth and at the same time decarbonizing our economic activity. Chancellor Merkel explained that "We believe we as a country can be a trailblazer for a new age of renewable energy sources. We can be the first major industrialized country that achieves the transition to renewable energy with all the opportunities-for exports, development, technology, jobs-it carries with it" (Cole 2011).

But if Germany is a barometer of progress on these wildly disparate policy goals, then the current forecast is for unpredictable weather ahead. Peering a bit deeper into that open pit coal mine I stood above helps to explain why.

\section{Leipzig, Lignite, Landscape}

Leipzig is about an hour south of Berlin by train in the former East Germany and is a city with a rich history far in excess of its current standing. Once a home to Bach, Wagner, Mahler, and Mendelssohn, Leipzig boasts a proud tradition in music, today carried on through musical festivals that span the gamut from rave to classical. It was also home to Goethe, Germany's most famous author. Today one can find his characters Faust and Mephistopheles standing outside Auerbachs Keller in the Mädlerpassage, where visitors can rub their toes for good luck.

Leipzig's political history is equally as grand. It was where Napoleon's army experienced its great 1813 defeat, commemorated 100 years later with the spectacularly massive Völkerschlachtdenkmal monument not far from the city center. The protests that culminated in the fall of the East German government and the reunification of Germany in 1990 began in Leipzig as regular Monday demonstrations in the 1980s. Citizen gatherings at the St. Nikolai Church in 1989 eventually led to massive, non-violent protests that ultimately contributed to the collapse of the German Democratic Republic (GDR) and the subsequent tearing down of the Berlin Wall. Even during my latest visit, a small group of protesters carried on the Monday tradition outside the St. Nikolai Church across from my hotel. 
In addition to all this history, Leipzig also has the distinction of sitting on top of one of the world's richest seams of lignite, or brown coal, dozens of meters thick lying just below the surface. Other concentrations of subsurface lignite in Germany can be found farther east, in a remote region near the Polish border, as well as in the Rhine River Valley in the west, where hard (or black) coal and the traditional German industrial region is also found. Most of the brown coal is used for domestic power supply —in 2007 lignite was responsible for about one-quarter of Germany's power production with the coal burned in power plants near to the open pits where it was mined. This arrangement means that lignite provides a very inexpensive and secure source of energy, essentially requiring no transportation, much less across borders. Just over 10 percent of lignite production in 2007 came from the Leipzig region. ${ }^{1}$

I have written a bit on Germany's energy and climate policies, but as a non-German-speaking-but-frequent-visiting academic, my own perspectives emphasize the technocratic aspects of policy and rarely engage the landscape of German culture and politics. So when my colleague Matthias Gross offered to take me on a tour of some of the countryside and open pit mines south of Leipzig, I could not pass up the opportunity to learn something more about this fascinating country. Gross, a sociologist at the Helmholtz Centre for Environmental Research, has studied the Leipzig region's relationship with its open pit coal mines (Gross 2010).

Prior to reunification this region of eastern Germany was essential to East Germany's desire to achieve energy self-sufficiency. Achieving such a goal lay in the realm of what might be considered-in the terminology of Functowitz and Ravetz and invoking Thomas Kuhn-just a situation of "normal science." Here values are not contested, but are clear, and the facts are not uncertain-the coal lies just beneath the surface, and energy self-sufficiency means getting to it. Hence the GDR embarked on a massive project to mine the sub-surface coal. When political change occurred this context changed as well.

\section{Obliquity in Decision Making}

Gross (2010) notes that in the 1980s East Germany was the world's largest producer of brown coal. When reunification took place it meant profound change, literally overnight. No longer was there such a need for reliance on dirty brown coal, as energy self-sufficiency was 
no longer a regional or geopolitical imperative. More important, the former East Germany saw changes in its demographics and in its national culture. For instance, its population declined rapidly as its citizens took advantage of the absence of a border. Leipzig, which never recovered from extensive damage incurred during World War II, saw a long-term trend of deindustrialization accelerate after reunification, losing about 90 percent of its industrial jobs and 20 percent of its population during the 1990s, joining about 1.5 million residents who left the former East Germany since $1990 .^{2}$

In addition, East Germany became reunited with a country that only several years before had discovered the Klimakatastrophe (literally "climate catastrophe") memorialized in the famous cover image from Der Spiegel showing the Cologne cathedral under water. The notion of Klimakatastrophe galvanized public opinion and political agendas around a common theme, which was consonant with aspirations for a unified Germany in a unifying Europe and the increasing salience of environmental issues in the aftermath of the 1986 Chernobyl accident.

However, despite the seeming ever presence of appeals to the importance of "climate protection" in Germany, actual policymaking does not often live up to expectations. Beck at al. (2009: 16) have written that despite Germany's oft-stated commitment to achieving climate policy goals, the reality of policy implementation often falls short of these ideals: "Policy statements sway between proclaiming ambitious targets, on the one hand, and preference for the incremental implementation of these targets, on the other ... the primary goal was to prevent imposing regulatory burdens that would impair the competitiveness of German industries and their attractiveness for foreign investors."

From this perspective, post-reunification Leipzig provides a political microcosm of larger German energy policies, reflecting a need to achieve several apparently contradictory goals at the exact same time. How was Germany to integrate the resource-based economy of its former communist east with the market-based industrial giant of the west in a manner consistent with the broader national commitment to environmental protection and some semblance of equity between the two former nations? This question provides a textbook example of a situation of post-normal science, with facts uncertain, values disputed, stakes high, and decisions urgent.

The answer to this question in the Leipzig region was-in the context of decision-making strategies appropriate for situations of post- 
normal science-absolutely brilliant, and a fine example of what economist John Kay (2010) calls an "oblique" strategy-going in what appears the wrong direction in order to arrive at your destination via an unexpected route. The strategy was oblique in the sense that region decided that the best way to move beyond coal would be to mine it and burn it as a bridge to a post-coal future.

The subsurface lignite seams in eastern Germany sit in a high water table, which means that groundwater needs to be pumped out of the open pits as the coal is removed. When the mine is spent and the pumping is stopped, the groundwater naturally returns over a period of many years or decades, filling the pit and forming a lake. During our tour of the region south of Leipzig, Gross explained to me that the GDR considered brown coal to be such an important source of energy independence and security that it had planned to mine the coal to exhaustion. The plans for mining were so extensively that it would literally leave Leipzig as an island as the surrounding environs were dug up, the coal removed and new lakes formed. Entire villages were even destroyed and moved in order to make way for the open pits. Gross explains that 470 square kilometers of the landscape had been mined by the late 1980 s.

Following reunification, the unique geological features of the landscape provided an opportunity for the region to move beyond its dirty industrial past to a clean and green future. The region would transform the spent mines to create a lake district-Neuseenlandschaft (lit. the "New Sea Landscape")—that would be championed for its environmental and recreational benefits. The website for the Leipzig New Lake Land cries out, "Where once the coal industry characterized the landscape you can find today most interesting facilities for recreation. Discover the unique changes of the scenery and the contrast between cultural scenery, active mining and landscape design. Come and see a region with a future!"

The region was applying policy obliquity to turn what might have been considered its greatest weakness into its greatest strength. Of course, the great irony of Leipzig's post-coal future is that for it to be realized requires burning a good deal of coal-a hallmark of an oblique policy strategy is that success sometimes requires actually going in a direction that seems counter to your goals.

With Matthias as my guide, we visited several open pit mines in various stages of their lifetime. I was surprised to see on the various tourist information signs expected dates for completion of mining operations stretching out toward mid-century. The commitment to con- 
tinuing the mining is so strong that in 2007 a mining company paid $\$ 4.2$ million to relocate a stone church that had stood for 700 years from one town to another in order to access the coal underneath (Associated Press 2007). This part of Germany may have a post-coal future, but that future lies pretty far off.

\section{Awareness of Nonknowledge Versus Constructed Ignorance}

Ignorance is the neglected sibling of uncertainty. There is of course a literature on ignorance that includes scholars such as Keynes, Knight, and Schackle, but this literature has not found its way very far into the fields of science and technology (for exceptions, see Rayner [2012], and sources cited therein). The notion of "decision making under uncertainty" has become a popular topic, and in the United States even has a federal science program with this name, but "decision making under ignorance" has yet to make a mark. Two aspects of ignorance are of particular note, first our awareness of ignorance and second, those steps we take to remain ignorant, including of our own ignorance.

According to Gross (2010), the open pit mining near Leipzig (and also Lusatia near the Polish border) have "changed the landscape on a scale that is unique in world history" and today the transformation of Leipzig's lake district is "the largest landscape construction site in Europe." What that means is that the engineering and the politics have been occurring in a state of not just fundamental uncertainties, but areas of complete ignorance, where we don't even know what we don't know. Decision makers in the Leipzig region know the future that they want to see realized, they just haven't known exactly how they are going to get there. Even so, until recently, this situation has proved manageable through a commitment to learning by doing and adjusting course based on the lessons of experience.

Policymaking has gone forward, Gross argues, because politicians, experts, and citizens recognized the fundamental limitations to what they know, and can know and acted incrementally while paying close attention to the outcomes of action. Would the water-filled mine pits collapse from the side? Would the water be contaminated? When would the projects be completed? Would investors actually come? Would the effort actually work? Such questions could only be resolved through experience, not predictive science. 
Acquiring experience required taking action and then seeing how things worked out. Decision making in the lake district region proceeded based on trial and error, with no two lake administrations following exactly the same plan, a strategy that academics have often called "adaptive management." Gross (2010: 141) writes, "The limited knowledge and predictive capacities of science were not seen to be signs of poor science. Instead, the actors agreed on what was not known and took it into account for future planning." This is not "decision making under uncertainty" "decision making under ignorance." Awareness of ignorance actually opens up possibilities for political compromise and policies that proceed incrementally based on the feedback of practical experience. Agreement on facts as a prerequisite to action is not necessary, so long there is an agreement to learn based on experience. A shared commitment to a particular further helped to underpin an incremental, learning-by-doing approach.

Gross describes this explicit awareness of ignorance as "nonknowledge," which is a direct translation of the German concept of Nichtwissen and a concept that he traces back to Socrates. The English language does not have a common term for such an orientation.

Nichtwissen has long been recognized, and finds its way into various literatures such as the distinction between risk and uncertainty formulated in 1921 by economist Frank Knight. Knight explained that risk refers to situations where probabilities are measurable and calculable, uncertainty is when they are not. Such Knightian uncertainty is consistent with the notion of ignorance as used by Gross. Ignorance is also theme throughout the writings of John Maynard Keynes, who explained that there are some things, like the price of copper years in the future, for which we simply cannot provide any meaningful probabilities. In recent years awareness of ignorance has entered popular discourse through an oft-repeated characterization provided by Donald Rumsfeld, secretary of defense under President George W. Bush, who in a famous press conference expounded on a taxonomy of "known and unknown unknowns." Nichtwissen is important because decision making necessarily takes place in the context of ignorance. There is simply a lot we do not and often cannot know.

Nassim Nicholas Taleb's (2007) notion of the "black swan" event makes sense only in the context of Nichtwissen. The notion of the "black swan event" is commonly used to describe events that are simply rare with high impact, but as presented by Taleb, the concept actually refers to events of high impact that are wholly unexpected but rationalized after the fact. A black swan thus emerges not simply from 
the long tails of a probability distribution, but from the region of the unanticipated, from our dark and murky areas of ignorance. If we understood and could characterize uncertainties associated with rare but extreme events, they would be exactly that, rare but fundamentally not a surprise.

Today not only do we tend to overlook Nichtwissen, but we go to great efforts to try to make it disappear from sight. Our era is characterized by appeals to certainty and control, which are typically grounded in invocations of science. For instance, the disaster that engulfed the Fukushima nuclear facility may have been a black swan event, but only because we made it so by putting hard limits on what we chose to see as possible. The backup power supply for the reactor complex was built next to the reactors themselves; newer facilities had the backup supply in reinforced buildings at a more secure location (Shirouzu and Dawson 2011). The design flaw was apparently recognized by engineers, but ignored by regulators. The disaster was only unexpected because available knowledge that suggested the possibility of a disaster was ignored. The Fukushima black swan was of our own creation.

Enlightened awareness of Nichtwissen is a rarity in today's politics, but as the Fukushima case illustrates, we often work hard to create such areas of ignorance. One of the most common issues that we try to ignore is the magnitude of our ignorance itself. Such ignored ignorance helps to maintain the pretense of knowing and control that characterize our era of scientized decision making.

Steve Rayner (2012) of Oxford University provides a set of concepts helpful for describing our willingness to create and maintain, but not acknowledge, areas of ignorance. Through such "social construction of ignorance" we create intellectual no-go zones- "institutionalized forgetfulness" in Rayner's words-in order to "maintain the organizational arrangements of societies and organizations" (2012: 110). He explains that traversing the boundary between institutionalized ignorance and common knowledge can be "uncomfortable" in the sense that it "may undermine the organizational principles of a society or organization" or "not admitting such information may also have serious deleterious effects on institutions, either directly or by making them prone to criticism from other parts of society that they "ought to have known." The regulators overseeing Fukushima certainly avoided causing problems by ignoring the design flaw sitting in plain sight.

Ignorance about Nichtwissen is a particularly interesting subset of the social construction of ignorance. A tension between Nichtwissen 
(awareness of our ignorance) and the social construction of ignorance (efforts to maintain our ignorance) is where today we find considerable political conflict. This is particularly the case in policy issues that are highly "scientized" in which competing sides in a political debate invoke scientific certainties - and at times quantifiable uncertaintiesin order to support their calls for action or inaction.

For instance, the political conflict over climate change is typically associated with opposing sides who express competing certitudes as a basis for advocating their preferred course of policy. Ironically enough, both sides of this debate tend to share obliviousness to Nichtwissen. The shared appeal to the certainties of science leaves no room for admissions of ignorance, which they often fear might be interpreted as giving succor to their political opponents by undermining their own claims to certainty. Ignoring our ignorance in this case diverts attention away from common interest options such as accelerating decarbonization through expanding energy access, improving security, and lower costs as well as improving resilience to extreme weather events, options that do not depend on scientific certainties about climate change to make sense.

The aversion to admissions of ignorance exists not only in the hyper-politicized public debate over climate change, but has found its way into the science as well. Consider that in preparation for its fifth assessment report, the Intergovernmental Panel on Climate Change prepared guidance for its contributors on how to handle presentation of uncertainties. The guidance drew on a literature review that identified various approaches to characterizing uncertainties, one of which was "effective ignorance" where "when knowledge of factors governing changes is low and plausibility of justifications for change is weak." However, in its guidance the IPCC decided to adopt all of the categories in the literature review but to selectively ignore the category of "effective ignorance" thus providing an excellent example of the social construction of ignorance about ignorance itself. ${ }^{3}$

\section{German Energy Policy Blows with the Wind}

The dynamics at play in the Leipzig new lake district are also at play in the larger context of German energy policy. Just as the brown coal mines offer an oblique bridge to a post-coal future, nuclear power offered a bridge to a post-nuclear future. But in the aftermath of the Fukushima disaster, it seems that Germany's energy bridge has now 
been burned, as the country has decided to eliminate all nuclear power by 2022, with ambitious plans to rely on wind and solar power to meet demand. It is difficult to envision how Germany can in the near term both eliminate nuclear power and reduce carbon dioxide emissions. Indeed, through 2020 it is expected that Germany's carbon dioxide emissions will increase by 40 million tons per year (Chestney and Cowhig, 2011).

Germany has long been at the forefront of efforts to put a price on carbon, having championed the European Trading Scheme and a domestic eco-tax, which began in 1998. Yet, from 1998 to 2008 (the most recent year that comparative data is available) Germany's economy became 18 percent less carbon intensive while that of the United States, with no price on carbon became 19 percent less carbon intensive. From 2000 the values are 12 percent for Germany and 16 percent for the United States. ${ }^{4}$ So whatever effects that carbon pricing may have had in Germany, and indeed across the European Union, it has shown little evidence of accelerating decarbonization at a rate greater than business as usual or that experienced elsewhere without such a policy.

What this means is that Germany will have to do more in the future than it has in the past to meet its ambitious emissions reduction goals. Yet, reflective of the ambivalence explained by Beck et al. (2009) in July 2011, German members of the European Parliament helped to vote down a proposal to increase the European commitment to emissions reductions from 20 percent to 30 percent from 1990 levels. The decision left European and German climate policies adrift, with the decision to abandon nuclear power makes achieving emissions reduction targets much more difficult. Under the nuclear phase-out, business-as-usual carbon dioxide emissions from electricity generation in Germany would increase by 8 percent from their current levels, a far cry from an accelerated reduction.

However, prior to the nuclear phase-out decision, for a while at least, Germany was at the forefront of a different approach-rather than trying to motivate innovation by increasing the costs of fossil fuels the alternative was to implement policies focused on making clean energy cheaper. At the end of October 2010 the Bundestag approved Chancellor Merkel's proposal to amend the Atomic Energy Act to extend the life of Germany's seventeen nuclear power plants. A new nuclear fuel rod tax and collection of extra profits from the operation of the nuclear plants would lead to a financial windfall of close to $\$ 40$ billion over the extended lifetime of the plants. These new funds were 
to have been used as significant resource to support a new Energy and Climate Fund focused on investing in clean energy and efficiency gains.

Germany was going to move in what appeared to be the wrong direction from the standpoint of its national political preferences-in the direction of nuclear-in order to eventually succeed in their longterm aspiration of getting away from using nuclear power while decarbonizing its economy. Merkel had decided to price contemporary energy supply to provide the resources to invest in tomorrow's energy supply, under a long-term goal of reducing reliance on fossil fuels and nuclear power to zero by mid-century. This approach-a nuclear bridge-emphasized a much more direct approach to innovation than that embodied by strategies that focus mainly on trading or setting a price on carbon.

The nuclear bridge lasted until 11 March 2011, when a powerful earthquake occurred off the coast of northern Japan. The immediate consequences of the earthquake and the massive tsunami that followed included more than 15,000 deaths. The event also flooded the Fukushima Daiichi nuclear power complex, crippling the reactors and backup power supply, setting the stage for a slow motion disaster that played out in the weeks and months that followed.

We may never know if Germany had set forth on an effective new model of energy and climate policy because in the aftermath of the Fukushima nuclear disaster Merkel decided to abandon that nuclear bridge by shutting down all German nuclear power in the near term. Instead, Germany has embarked on a different kind of experiment, which will see how far and how fast it can rely on renewable energy, with fossil fuels being the obvious fallback source of energy supply.

It was this context that framed Chancellor Merkel's decision to go back on her earlier change of course to extend the life of the country's nuclear power plants. Merkel's flip-flop on nuclear power, in hindsight, should have been eminently predictable. Fukushima was merely the precipitating event-the more important tremor occurred in the German political landscape when in April 2011 opinion polls showed that the Green Party displaced the Social Democratic Party for the first time. With Greens long favoring a dismantling of the country's seventeen nuclear power plants responsible for about one-quarter of electricity generation it became a matter of political expediency for Merkel to change course. The historic election in the state of Baden-Württemberg in southwest Germany that brought the Greens to power no doubt had the chancellor thinking about the interests of possible future coalition partners. Roland Nelles (2011), writing in 
Der Spiegel, disparaged the decision as "Merkelism," which he characterized as being based on two principles of political expediency: "The first is that, if the people want it, it must be right. The second is that whatever is useful to the people must also be useful to the chancellor."

Though the nuclear phase-out may prove to be an effective strategy of triangulation in the context of Germany's parliamentary politics, it has put nation in the position where something has to give. Even with nuclear power, participation in the European Emissions Trading Scheme and the uncontroversial nature of climate policies among the general public, in recent years Germany has seen a "dash for coal" in part due to the expectation of a nuclear phase-out (before Merkel's flip then flop). According to an analysis by Michael Pahle (2010) of the Potsdam Institute for Climate Impact Research, in 2009 Germany had ten new coal plants under construction and plans for about thirty additional coal plants worth of energy supply. Despite various pronouncements to the contrary it simply does not seem mathematically plausible for the country to eliminate nuclear power and reduce carbon dioxide emissions over the next decade.

\section{What Happens When Politicians Promise the Impossible?}

The answer would obviously seem to be to expect policy failure. But in today's politics, elected officials and their expert advisers typically respond by telling their constituents exactly what they want to hear. In the United States this plays out as promises made by the government to pay pensions, medical care, farmers, students, and a panoply of other government services and entitlements while at the same time committing to never increasing taxes. In Germany this logic has manifested itself in a commitment to stop using nuclear power and fossil fuels, while simultaneously keeping the lights on and meeting strict emissions reduction commitments. (And Europe more generally faces a similar circumstance with respect to the Euro and various debt crises.) How are such goals to be met? "We don't know" are rarely, if ever, uttered by politicians anywhere, but if certain circumstances demand awareness of Nichtwissen, each of these cases would seem to qualify.

Ignoring ignorance may be pragmatic politics in the sense that citizens are told that they can have the impossible, but it is the opposite of pragmatic policymaking for the simple reason that ignorance exists 
and effective action often depends on acknowledging it and then dealing with it. As an intellectual orientation, pragmatism tells us that we should believe in what works. It does not tell us that what we believe will work. Ultimately, experience is the arbiter of belief, not the other way round.

German politicians who tell their constituents that they can at once shut down seventeen nuclear power plants and meet aggressive goal for reducing carbon dioxide emissions may find that this message "works" in the sense that many people find it appealing and worth supporting. The only correct answer to the question of how to meet aggressive emissions reduction goals without reliance on nuclear power is "perhaps, but we don't know for sure" - the answer lies in that unmapped region of Nichtwissen. Wise policy in such a situation means being prepared for what might be characterized in Steve Rayner's (2012) terminology as "uncomfortable knowledge" —in this case policy failure. German policymakers would be wise to plan for and to prepare the public for the possibility that it cannot achieve all that it has promised.

\section{Building Bridges to the Future}

Back in Leipzig, Matthias Gross explained to me that in recent years the optimism and healthy awareness of Nichtwissen that had characterized the successes in the creation of the new lake district has begun to break down. He writes in his book "[A]n approach that originally acknowledged ignorance and offered space for negotiations to move on in the face of unknowns has led to a false assumption that certainty via expert knowledge is the only possibility to move forward" (Gross 2010: 157). Like so many other contexts, Leipzig lake district decision making has become scientized, with expectations that uncertainty is a quantity to be reduced prior to the making of decisions. Ignorance is thus ignored and planning should follow more of a top-down model. Gross explains (2010: 157) that the "lack of acknowledgement of nonknowledge has been a major source for some of the waning public confidence in the possibilities of the landscape design of former strip mines."

Awareness of our ignorance-the creation of nonknowledge-is important in democracy because it opens the way for flexible policies that learn and evolve based on experience, subject to the approval of the plebiscite. Such awareness also sensitizes the public to the possi- 
bility -indeed the inevitability — of policy failure. The alternative is a "lock in" to strategies that are far more brittle and incapable of evolving. Leipzig's lake district might be moving in this direction and Germany's energy policies might also be in such a state. It seems that awareness of ignorance is a difficult stance to maintain.

That sunny German spring day in 2011, Gross and I ended our tour of the mining district south of Leipzig at a posh café sitting on a dock out over the water of the Cospudener See-one of the completed lakes that had once been an ugly gash in the earth much like the one I had stood before earlier that day. Trout swam lazily in the shallow, crystal clear water below us. Sailboats filled the marina next door and vacation and retirement homes lay just past the dunes. People strolled and biked by on the path adjacent to the waterfront. The omnipresent wind turbines spun lazily off in the distance. My seafood pasta was delicious, the discussion invigorating. It was hard to believe that this spot was once an industrial blight.

Effective decision making in the context of situations that are characterized by conflicting values and deep uncertainties-including ignorance-will benefit from the perspective offered by Funtowicz and Ravetz on situations of post-normal science. In such situations the first step toward progress might be an oblique one, by admitting our ignorance and then dealing with resulting uncomfortable results. Policy analysts, politicians, scientists, and technocrats all seem to have an aversion to admissions of ignorance, which makes decision making under ignorance all the more challenging.

Sitting there in the gentle breeze in the transformed landscape enjoying my lunch and conversation with Gross I could almost imagine that Germany had figured out something really important about innovation, democracy, and building a better, shared future. Almost.

\section{Acknowledgments}

Thanks to Silke Beck, Holger Braun-Thürmann, Dennis Bray, Matthias Gross, Werner Krauss, Jörg Matschullat, Jerry Ravetz, Steve Rayner, Mike Schäfer, Jeroen van der Sluijs, and Hans von Storch. Also thanks to two anonymous reviewers. This essay benefited from discussions at a workshop on "Post-Normal Science: The Case of Climate Science" held in Hamburg, Germany, in May 2011 and organized by the Cluster of Excellence for Climate Science, University of Hamburg and the Institute for Coastal Research, Helmholtz Center Geesthacht. 
Roger A. Pielke, Jr. has been on the faculty of the University of Colorado since 2001 and is a fellow of the Cooperative Institute for Research in Environmental Sciences. Address: CIRES Center for Science and Technology Policy Research, University of Colorado, Boulder, 1333 Grandview Avenue, UCB 488, Boulder, CO 80309-0488, USA. E-mail: pielke@colorado.edu.

\section{Notes}

1. German coal data from Euracoal, http://www.euracoal.org/pages/layout1sp .php?idpage $=72$. Accessed 16 September 2011 .

2. Population data on Leipzig from http://www.pik-potsdam.de/urbs/leipzig.htm Accessed 16 September 2011.

3. I am indebted to Jeroen van der Sluijs for this observation.

4. These are my calculations based on methods described in Pielke (2010).

\section{References}

Associated Press. 2007. "Germany: Old Church Rolls to New Home." 1 November. Beck, Silke, Christian Kuhlicke, and Christophe Görg. 2009. Climate Policy Integration, Coherence, and Governance in Germany. Report of the HelmholtzZentrum für Umweltforschung. UFZ-Bericht, January, Leipzig.

Chestney, Nina and Jackie Cowhig. 2011. "German Nuclear Cull to add 40 Million Tonnes CO2 per Year," June 1, Reuters: http://www.reuters.com/article/2011/06/ 01/us-german-nuclear-carbon-idUSTRE74U2Y220110601.

Cole, Deborah. 2011. "German Nuclear Shutdown Sets Global Example: Merkel." Association France Presse, 30 May.

Funtowicz, Silvio, and Jerome Ravetz. 1992. "Three Types of Risk Assessment and the Emergence of Post-Normal Science." Pp. 251-273 in Social Theories of Risk, ed. Sheldon Krimsky and Dominic Golding. Westport, CT: Greenwood Press.

- 1993. "Science for the Post-Normal Age." Futures 25 (7): 735-755.

. 1994. "Uncertainty, Complexity and Post-Normal Science." Environmental Toxicology \& Chemistry 13 (12): 1881-1885.

Gross, Matthias. 2010. Ignorance and Surprise: Science, Society and Ecological Design. Cambridge, MA: MIT Press.

Kay, John. 2010. Obliquity: Why Our Goals Are Best Achieved Indirectly. London: Profile Books.

Knight, Frank. 1921. Risk, Uncertainty and Profit. Boston, MA: Hart, Schaffner, \& Marx.

Nelles, Roland. 2011. "Merkel's Nose for Populism Yields Another Victory." Der Spiegel, 31 May. http://www.spiegel.de/international/germany/0,1518,765903, 00.html

Pahle, Michael. 2010. "Germany's Dash for Coal: Exploring Drivers and Factors." Energy Policy 38 (7): 3431-3442.

Pielke, Roger A., Jr. 2010. The Climate Fix: What Scientists and Politicians Won't Tell You About Global Warming. New York: Basic Books. 
$\square$ ROGER A. PIELKE, JR.

Ravetz, Jerome. 2004. "The Post-Normal Science of Precaution." Futures 36 (3): 347357.

Rayner, Steve. 2012. "Uncomfortable Knowledge: The Social Construction of Ignorance in Science and Environmental Policy Discourses." Economy and Society 41 (1): 107-125.

Shirouzu, Norihiko, and Chester Dawson. 2011. "Design Flaw Fueled Nuclear Disaster." Wall Street Journal, 1 July, http://www.theterranews.com/content/?p=44892.

Taleb, Nicholas N. 2007. The Black Swan. New York: Random House. 